\title{
Geological and geomorphic investigations on palaeo-landslide dammed the Tamourghout River (Middle Atlas, Morocco)
}

\author{
Jamal Abbach ${ }^{1, *}$, Hajar El Talibi ${ }^{1}$, Said El Moussaoui ${ }^{1}$, Hinde Cherkaoui Dekkaki ${ }^{1}$, and Issam Etebaai ${ }^{1}$ \\ ${ }^{1}$ Faculty of Sciences and Techniques of Al Hociema, Abdelmalek Essaadi University, Tetouan Morocco
}

\begin{abstract}
The Middle Atlas Mountains in Morocco are best known for their slope-active movements, where lithology, topographic relief, and seismotectonic are likely to cause slope instability problems. This study focused on geomorphological and geological investigations on palaeo-landslide blocked and dammed the Tamourghout river main bed (Taza, Morroco). The paper is essential due to the enormous proportions of the landslide and also because of the vast watershed lock-up by the dam (Tamda lake) and the recognition that a Tamourghout river has been and can be obstructed by a permanent landslide
\end{abstract}

\section{Introduction}

A great diversity of natural lakes characterizes the Atlas domains of Morocco. They are typical and educational examples in the reconstruction of the geological history of the Atlas Mountains. Their genesis depends on their origins which are generally caused by natural phenomena.

Lake Tamda, suspended between the altitudes of the northern Middle Atlas, is located $80 \mathrm{~km}$ southeast of Taza in the foot of Boublane at $1500 \mathrm{~m}$ altitude; it is a typical and educational example of a natural lake landslide origin. Its natural dam was created by sliding a gigantic carbonate body, blocking the hydrographic network and giving rise to a large water reservoir with a length of more than $4 \mathrm{~km}$ and an average width of more than 200 meters.

\section{Study area and geological setting}

The study area is located in southeast Taza in the Magharwa region (Fig. 1), belonging to the folded part of the Middle Atlas chain (Fig. 2), near the Central Middle Atlas Fault (ACMA) boundary.

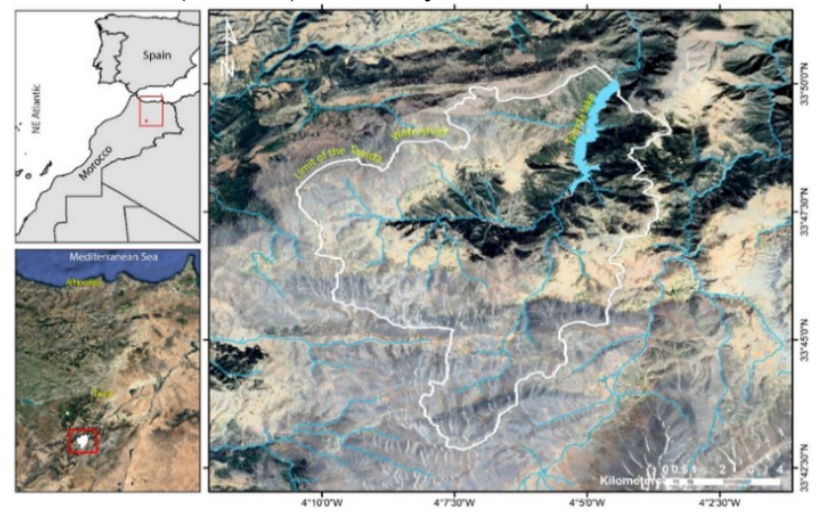

Fig. 1. The general setting of the study area with the location of lake Tamda
It includes two large mountain ranges, Tazekka hill in the west and Bou Ibalne in the East. The tectonic structure corresponds to large synclinal basins (Tamatroucht) with axes parallel to the chain Nar narrow anticline wrinkles sometimes intrude with gabbroic rocks [1-4].

The geological bedrock consists of Paleozoic, partly Carboniferous basement in exposed the Tazekka hill and covered by thick carbonates, clays, and basalts units mainly Mesozoic-Quaternary [4-8].

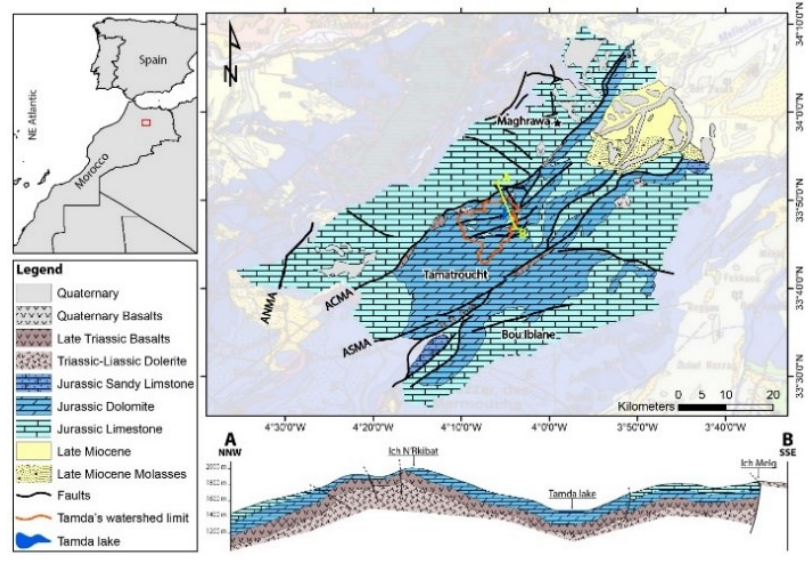

Fig. 2. Simplified geological map and geological section indicating sediments exposed in the study area (modified after [13])

\section{Climate setting}

In the Middle Atlas and surrounding areas, the climate is warm and temperate. The study area is characterized by large spatial variations of rains influenced by the windward effect, elevation, and aspect. The Fès-Taza corridor is characterized by a rainy winter rainfall regime, extending from November to April, and a relatively dry to arid summer, going from June to September. The annual rainfall average varies between $500 \mathrm{~mm}$ in the west (Sebou-Inaouène confluence) and $700 \mathrm{~mm}$ east of Taza

* Corresponding author: jamalabbach21@gmail.com 
(Table1). Nevertheless, the mountainous areas bordering the basin are much more watered: up to $1500 \mathrm{~mm}$ in the southeast, on the peaks of the Djebel Tazzeka, and a little more than $1000 \mathrm{~mm}$ on the high northern slopes. However, the interannual precipitation variability is quite large, but with a total number of rainy days consistently low, 60 to 70 days on average per year. The snowmelt is also essential on high cliffs. It feeds groundwater supply and promotes limestones dissolution and the development of karst [9].

Table 1. Average annual rainfall and temperature between 1980 and 2019 (Data from National Forestry Research Center (CNRF)

\begin{tabular}{|c|c|c|c|c|c|}
\hline Station & $\begin{array}{c}\text { Latitude } \\
(\mathbf{N})\end{array}$ & $\begin{array}{c}\text { Longitude } \\
(\mathbf{W})\end{array}$ & $\begin{array}{c}\text { Altitude } \\
(\mathbf{m})\end{array}$ & $\begin{array}{c}\text { Rain } \\
(\mathbf{m m} / \mathbf{a n})\end{array}$ & $\mathbf{T}\left({ }^{\circ} \mathbf{C}\right)$ \\
\hline $\begin{array}{c}\text { Bab } \\
\text { Boudinar }\end{array}$ & $34^{\circ} 04^{\prime}$ & $4^{\circ} 07^{\prime}$ & 1570 & 1220 & 19 \\
\hline Tazekka & $34^{\circ} 11^{\prime}$ & $4^{\circ} 12^{\prime}$ & 1380 & 851.4 & 18 \\
\hline Taza & $34^{\circ} 13^{\prime}$ & $4^{\circ} 01^{\prime}$ & 500 & 524.5 & 23 \\
\hline Bou Iblane & $34^{\circ} 14^{\prime}$ & $4^{\circ} 02$ & 2500 & 678.6 & 18 \\
\hline Tamatroucht & $34^{\circ} 14^{\prime}$ & $4^{\circ} 01^{\prime}$ & 2450 & 678.4 & 17 \\
\hline
\end{tabular}

\section{Methods}

The proof for the landslide dam has been assembled from field investigation, analysis of geological maps, and digital elevation models (ASTER-GDEM V2). Geomorphic parameters are collected from bibliographic archives analysis or estimated via cartographic and satellite imagery interpretation. We opted for a multidisciplinary approach to study the landslide: Slide morphology has been studied through satellite images. With the GIS system, we mapped and highlighted the elements of the slide. Direct field observations and photographing have been supplemented by field mapping. We focus on identifying specific characters of the karst features and, due to the specificities of the geological context, their characterizations as geo-trigger off a landslide.

\section{Results and Discussion}

\subsection{Geomorphic characterization of Tamda watershed}

The study area of Tamda (Fig. 3) has sub-vertical slopes where the slopes vary between 50 and $70 \%$. The watershed from about $60 \mathrm{~km}^{2}$ is surrounded by a set of clips that exceed $2000 \mathrm{~m}$. A DEM with $30 \mathrm{~m}$ resolution was a great source to generate various topographic factors, which influence the landslide activities in this area. From this DEM, three thematic data layers were extracted, which are:

\subsubsection{Hypsometry}

The Hypsometry of the Tamda watershed is spread over several fractional surfaces as a function of altitude, as shown by the hypsometric map (Fig. 3A). The hypsometric classes between 1800 and $1900 \mathrm{~m}$ mark $20.40 \%$ of the watershed with a surface that exceeds 16 $\mathrm{km}^{2}$. The minimum Hypsometry is $1450 \mathrm{~m}$ which is the lake bottom point. It can be concluded that the studied terrain is characterized by considerable Hypsometry and reflects the mountainous dominance of the Tamda watershed

\subsubsection{Slope}

It consists of the maximum change in $\mathrm{z}$-value from each cell. The slope is very steep throughout the area, especially in the dam's vicinity (Fig. 3B). It varies between 0 and $89^{\circ}$ on the surface of the watershed. We have located in the field an extreme escarpment beyond the dams; the concentration of the maximum slope is very distinct in the northern part of the watershed, precisely near the slide body. We can also note on the map slopes areas with zero slopes that inevitably provide information on tectonic and/or karst depressions. The value of the slope that dominates the watershed is between $10^{\circ}$ and $30^{\circ}$; thus, the studied area has a very particular inclination

\subsubsection{Aspect}

refers to the direction of the maximum values of those changes from each cell to its neighborhood in the output raster. The values of each cell in the output raster indicate the compass direction that the surface faces at that location. It is measured clockwise in degrees from $0^{\circ}$ to $360^{\circ}$ site ranges from $1^{\circ}$, which corresponds to the flat areas having no downslope, to $356^{\circ}$ North. All the directions, as well as the corresponding degrees, are described in Figure 3C. Slope exposure in our study area is dominated mainly by North orientation $15.34 \%$ and Northeast $14.25 \%$. The orientation of the slopes in the study area influences especially the degree of instability on the exposed slopes North and NNE for the landslides. Slopes of the direction South, SSE, SSW show especially an erosion dominated by the streaming.

\subsection{Main features of the Tamda lake}

The Tamda dams lake has a very long form (Fig. 3D). The length can reach five kilometers; it is fed essentially by the alluvium precipitations; it fills up during the cold season when rainfall is plentiful, the water level drops in summer and dries up during the persistence of warm seasons. It is of type "fill-and-spill". The dike is located at an altitude of $1500 \mathrm{~m}$, and it is generally carbonated, covered by cedar; its height reaches 50 meters, its length and width measure $474 \mathrm{~m}$ and $426 \mathrm{~m}$, respectively.

The watershed's hydrology is characterized by an endorheic flow that feeds the Tamda Lake, blocked by a very huge carbonated sliding body and constitutes a rigid and impervious dike. The primary hydrological resources 
that feed the water reservoir are the rainfall and snowfall inputs drained by the different rivers and their effluents towards the outlet. The drying up of the lake is mainly done by evaporation and infiltration, notably by continuing the extensions of the mid-atlas fault with an N10 direction. The watershed of this water reservoir is dispersed over an area in the vicinity of $78.69 \mathrm{~km}^{2}$; its maximum length can reach $17,16 \mathrm{~km}$, its maximum width is $9.45 \mathrm{~km}$, and its perimeter is approximately $51.93 \mathrm{~km}$.
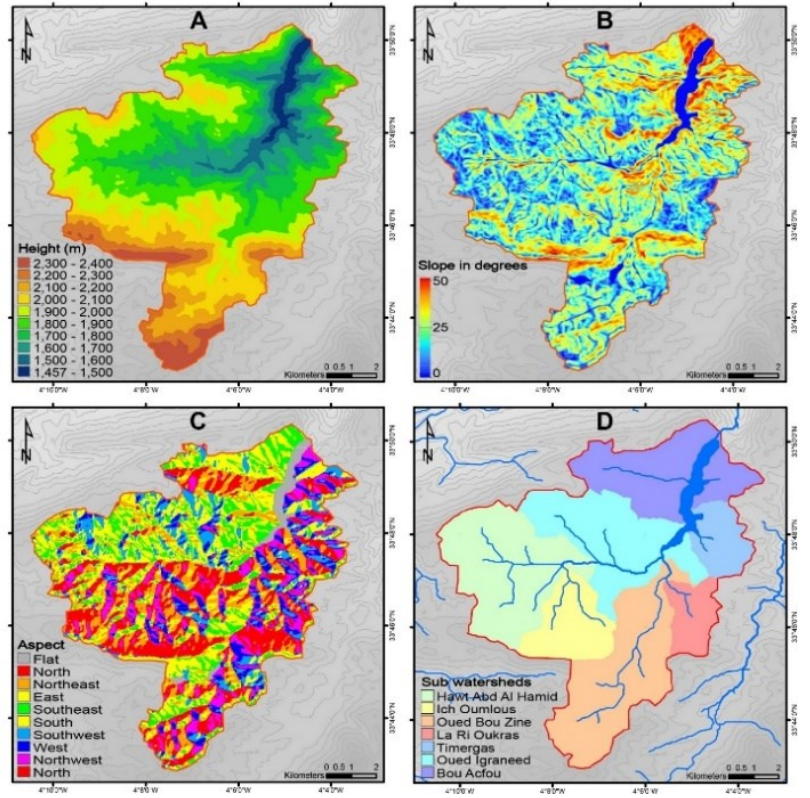

Fig. 3. the topographical characteristics of the Tamda watershed

\subsection{Karstification features}

The karst of the study area presents forms like rock cones, giant sinkholes, snow wells of the Jebel Bou Iblane, and skimmer of sinkholes rich in underground rivers. The respective roles of ancient climate conditions and the tectonic setting are difficult to specify. While, the genesis of the forms is replaced in the overall evolution of the Middle Atlas characterized by superimposition of rivers, the fluctuation of the Atlantic-Mediterranean watershed, and minor tectonic readjustments that guided karstification [9-11].

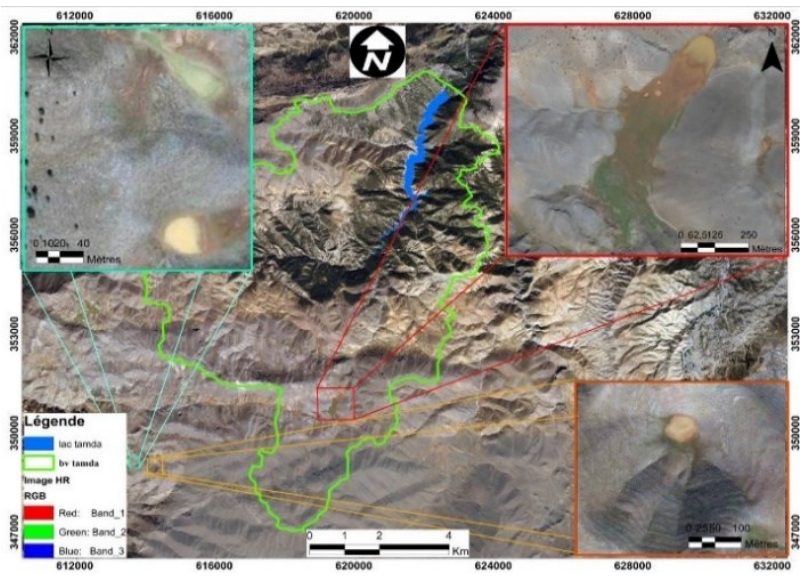

Fig. 4. A landscape presentation of examples of karst structures in the study area
Mounir et al. recognized in detail the karst forms of the central Middle Atlas near to Taza; this karst is essentially characterized by the variety of surface forms, lapidates, caves (Fig. 4), sinkholes, poljés, dry valleys, rock cones, and crypto karst developed in quaternary basaltic flows.

\subsection{Landslide characteristic}

Based on GIS analysis and geomorphic evidence, the landslide location and volume can be estimated. The length of the rock movement from the surface to the riverbed is $750 \mathrm{~m}$ with a width up to $1 \mathrm{~km}$ (Fig. 5). Given the slide oldness, it is hard to know the depth to the shear surface from the topography, and therefore any estimation of the slide volume is provisional. Studies of many of the significant landslides recommended that an expected average depth of $100 \mathrm{~m}$ is realistic. The volume of the landslide displaced on the river would then be at least a few hundred million $\mathrm{m} 3$ (750 to $1000 \times 92$ ).

The sliding body moved about $500 \mathrm{~m}$ and obstructed the Tamourghout bed, creating a landslide dam closely $1500 \mathrm{~m}$ high. The SE slope of jbel N'erkibat still shows the freshness of the main and lateral tearing scars. The sliding body crossed the bed of the Tamourghout river and ran on the opposite side of $300 \mathrm{~m}$ high, forming numerous thrusts and scarps of an anti-slope cliff. The main slope is serrated and sub-vertical $\left(30^{\circ}-60^{\circ}\right)$, with a vertical height of $800 \mathrm{~m}$. The deposits in the landslide dams are mainly composed of carbonate rocks (Fig. 5A-B), including limestone and dolomite Jurassic complex, sandy mudstone of the upper Miocene molasses units.

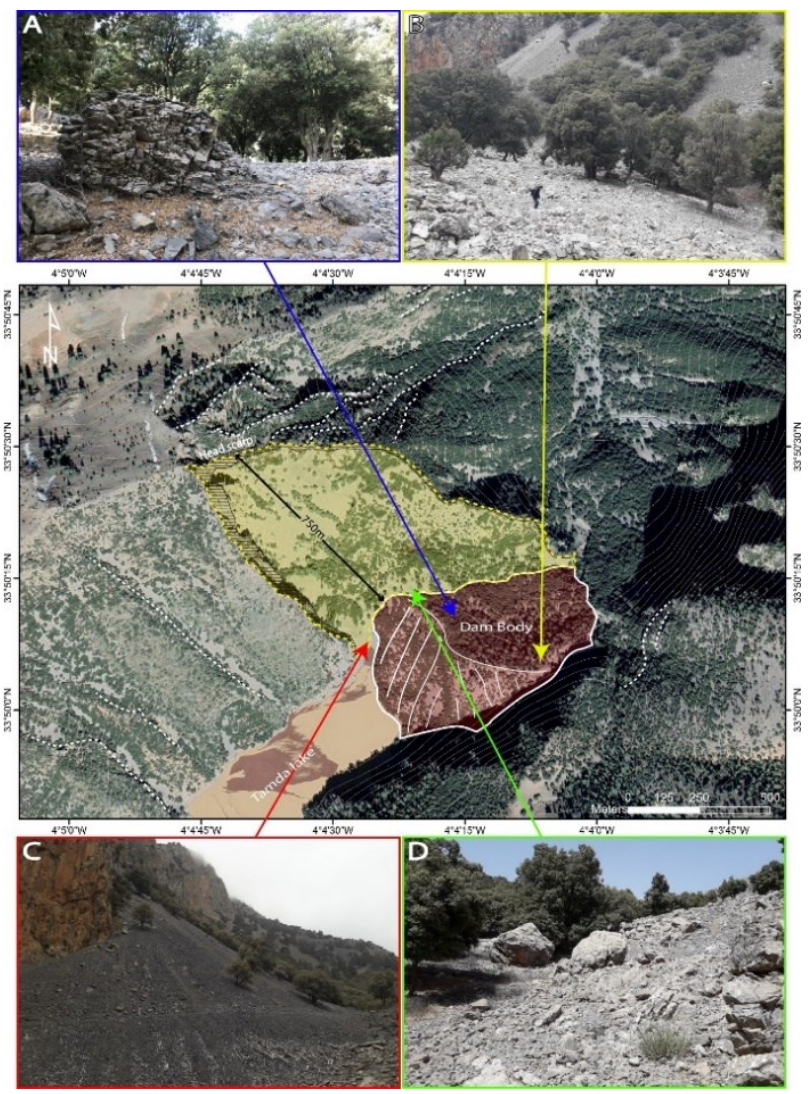

Fig. 5. The morphology of the main slide and its units. 
The field observations of the sliding surface allow us to classify the event in Rock/debris slide complex. This slide category is a large bulk of mostly dry rock debris caused by the collapse of a slope and run-up over a long distance [12]. Its speed can reach $10 \mathrm{~m} / \mathrm{s}$, and the volume is up to $100 \mathrm{~m} 3$. The moved distance of a rockslide frequently surpasses several kilometers, and the movement becomes evident by the run-up on the slope of the opposite side of the valley (Fig.6). On the study site, we were able to identify two types, the first one corresponds to active landslides (debris avalanches and debris flows) in the vicinity of the lake, and the second case corresponds to a sudden rock slide which caused the Ich Nrkibat phenomenal mass wich blocked Tamourghout river and create a large body of water. The sediment layers of the slide dams are heterogeneous and mixed with a wide variety of lithology and particle sizes. The main deposit area comprises fragments of fine sediments and debris mixed with large boulders and blocks with sizes ranging from $0.5 \mathrm{~m}$ to $5 \mathrm{~m}$ (Fig. 5C-D). The middle and lower layers are better preserved, not strongly disaggregated, and formed of the almost intact rock body.

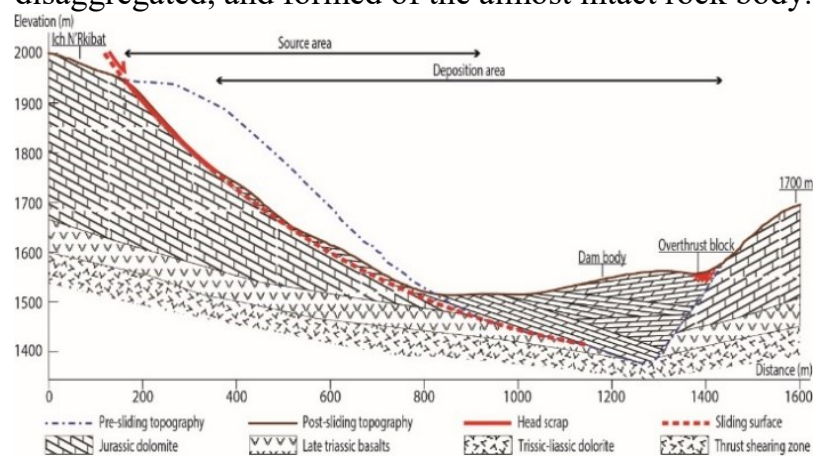

Fig.6 Geological section showing the lithology of the Tamda landslide

\subsection{Discussion}

Tamda is, without a doubt, a natural lake formed on the occasion of an immense catastrophic landslide, which blocked the deep valley of Tamourghout. This landslide is a slope instability process, which produces local geomorphic, hydrologic, and seismotectonic conditions. In fact, The Maghraoua syncline is one of the most fractured regions of the Middle Atlas. [13] has recognized two types of faults in the region: oriented faults NE and WNW oriented faults with expanding cracks. Thus, Tamda is located in a well-known tectonically active region with potential geological conditions for strong earthquakes [14]. The ACMA Fault is the main fault among the Tamourghout watershed, and it runs through this area along the valley. Based on historical seismic records, multiple historical seismic events with a magnitude of $\geq 6$ since 1755 occurred in the study area $[14,15]$. A seismic event triggered the landslide due to a replay of the central fault that probably accompanied the 11 May $1624 \mathrm{Fez}$ earthquake. This quake is of the worst natural disasters in the history of Morocco and caused severe damage in the city of Fez, Taza, and its surroundings [15]. This interpretation is also based on many observations, including the substantial dip of the limestone layers towards the SE (30-70 $\left.{ }^{\circ}\right)$; the imbalance situation testified by the outcrop of the Triassic clay downstream due to the river erosion.

Generally, The Atlas Mountains are often prone to slope instabilities [16]. Since the Villafranchien, tectonic movements have caused large hills broken into bulky blocks testifying to a tectonic paroxysm. The role of seismic movements in this context of landslides is not to be demonstrated because they occurred at all landscape scales [17]. Thus, most of the seismic epicenters studied in the Middle Atlas coincide with faults alignments [15] [18], which attests to a strong correlation between the earthquake and geological structure. The same neotectonic activities were widely discussed throughout the North Middle Atlas accident.

Furthermore, this study revealed that the existing geomorphic evidence is in agreement with the results of previous studies [16] [19] [20] that is to say that earthquakes could have occurred in the Middle Atlas, along the Tamourghout River. Through examinations of the landslide aspect, we can deduce that the lake dammed by the paleo-landslides of Tamda is considered the result of a large avalanche of rocks triggered by an earthquake. The incidence of the Tamda landslide will be controlled by the combined effect of geological (lithology), geomorphological and seismic factors. The landslide is very close to the NAMA fault. Therefore, it is assumed to have suffered strong tremors during the previous earthquakes. In addition, the slope escarpment, high local relief, the approximation of the fault, active tectonics and densely articulated strata all favor the reproduction of landslides [21-23].

Although precipitation and climatic conditions can contribute to the triggering of landslides, we exclude this possibility because the study area is located in a Mediterranean climate zone, with an average annual rainfall of less than $600 \mathrm{~mm}$. The paleoclimate records and modern meteorological observations show that the water vapors in the Middle Atlas and its adjacent areas mainly originated from the Mediterranean Sea [9]. In the upstream section of the Tamourghout River, the climate was relatively warm and humid. However, the temperature and precipitation showed noticeable decreases. The exposed rocks on both sides of the Maghraoua area are mainly hard volcanic rock intercalated with Limestone, which is well cemented and stable under natural conditions. During the late Holocene period, the study area was dominantly characterized by minimal rainfall and a dry climate [9]. Therefore, it could be inferred that it is less likely that any large dam-forming landslides (rock avalanches) be induced by rainfall.

\section{Conclusion}

Field investigation and geomorphic analysis were conducted to better understand the Tamda landslide formation process in Tamourghout river valley, Middle Atlas, Morocco. The integrated utilization of data obtained revealed that the large dams formed in the Tamda lake are housed in a picturesque site where a vast catastrophic landslide blocks the valley. It attests to the 
importance of abrupt natural events in the shaping of the relief. These events (collapse, landslide) would have been generated in Tamda elsewhere by the recent tectonic activity. Moreover, it turns out that the lithology and the flooded structure in the Middle Atlas are the main factors to explain the landslides genesis. Climatic conditions (humidity and cold) added to those of the vigorous tectonics were able to generate mass instabilities, capable of obstructing valleys as wide and as deep as that of the Atlas and subsequently formed the landslide-dammed lake.

\section{References}

1. B. Fedan, «Etude Structurale D'une Portion De L'accident Nord Moyen Atlasique Dans La Region Au S'v De Boulemane, Moyen Atlas Central, Maroc », p. 10.

2. [G. Colo, Contribution a l'étude du Jurassique du Moyen Atlas septentrional: Atlas de planches hors texte. Éd. de la Division de la géologie, Direction, Ministère, Royaume du Maroc, 1961.

3. A. Akasbi, D. Sadki, A. Akhssas, et B. Fedan, «Dynamique sédimentaire et contrôle tectonoeustatique des dépôts dans l'intervalle Toarcien supérieur-Bajocien inférieur du Sud-Est du Moyen Atlas plissé (Maroc) », p. 8.

4. H. Termier, «Etude géologique sur le Maroc central et le Moyen Atlas septentrional: Notes et Mémoirs du Service des Mines et de la Carte Géologique », Rabat Maroc, no 33, p. 4, 1936.

5. M. L. Arboleya, A. Teixell, M. Charroud, et M. Julivert, «A structural transect through the High and Middle Atlas of Morocco », J. Afr. Earth Sci., vol. 39, no 3 , p. 319-327, juin 2004, doi: 10.1016/j.jafrearsci.2004.07.036.

6. R. du Dresnay, «Données stratigraphiques complémentaires sur le Jurassique moyen des synclinaux d'El Mers et de Skoura (Moyen-Atlas, Maroc) », Bull. Société Géologique Fr., vol. 7, no 6, p. 883-900, 1963.

7. «Khalid OBDA et al..pdf». Consulté le: mars 19, 2021. [En ligne]. Disponible sur: http://www.geomaghreb.com/journal/volumes/Geomaghreb5/Khalid $\% 200 B D A \% 20$ et $\% 20$ al..pdf.

8. D. Sadkaoui et al., «Indices néotectoniques dans les sédiments du lac Ifrah (Moyen Atlas, Maroc) », Eur. Sci. J., vol. 11, no 14, 2015.

9. A. Taous, A. Tribak, K. Obda, R. Baena, E. LópezLara, et J. Bonilla, "Karst et resources en eau au Moyen Atlas nord-oriental », Geomaghreb, vol. 5, p. 41-59, janv. 2009.

10. J. Martin, «Le Moyen Atlas central, étude géomorphologique », 1981.

11. S. Mounir, N. Saoud, M. Charroud, K. Mounir, et J. Choukrad, "The Middle Atlas Geological karsts forms: Towards Geosites characterization », Oil Gas Sci. Technol. D'IFP Energ. Nouv., vol. 74, p. 17, 2019.
12. K. J. Hsu, « Catastrophic debris streams (sturzstroms) generated by rockfalls », Geol. Soc. Am. Bull., vol. 86, no 1, p. 129-140, 1975.

13. A. Sabaoui, «Rôle des inversions dans l'évolution méso-cénozoïque du Moyen Atlas septentrional (Maroc). L'exemple de la transversale El MenzelRibat Al Khayr-Bou Iblane », Thèse Sci., 432p, 1998.

14. T.-E. Cherkaoui et L. Asebriy, « Le risque sismique dans le Nord du Maroc », Trav Inst Sci, p. 225-232, 2003.

15. T. E. Cherkaoui, A. El Hassani, et M. Azaoum, « Impacts du tremblement de terre de 1755 au Maroc: histoire, société et religion. In «Witnesses of Chaos: aspects of the 1755 Lisbon earthquake» », Acad. Ciênc. Lisb., p. 53-68, 2017.

16. B. El Fellah, «Guelta Tamda (Moyen Atlas Plissé, Maroc): un exemple de lac de barrage naturel », Rev. Géographie Maroc, vol. 16, no 1-2, p. 115-126, 1994.

17. B. El Fellah, O. Azzouz, et L. Asebriy, «Sikha Asfalou: exemple de glissement sur la côte méditerranéenne des Bokoya entre Torrès et Badis,(Rif septentrional, Maroc) », Bull.-Réseau Eros., no 16, p. 222-231, 1996.

18. T.-E. Cherkaoui et L. Asebriy, « Le risque sismique dans le Nord du Maroc », Trav Inst Sci, p. 225-232, 2003.

19. I. Etebaai, «L'environnement actuel et le fonctionnement hydroclimatique de quelques systèmes lacustres dans le Moyen Atlas marocain: cas des lacs Ifrah, Iffer et Afourgagh », Universite Abdelmalek Essaadi Faculté des Sciences et Techniques Tanger, 2009.

20. B. Damnati, I. Etebaai, H. Benjilani, K. El Khoudri, H. Reddad, et M. Taieb, «Sedimentology and geochemistry of lacustrine terraces of three Middle Atlas lakes: Paleohydrological changes for the last 2300 cal BP in Morocco (western Mediterranean region) », Quat. Int., vol. 404, p. 163-173, 2016.

21. J. E. Costa et R. L. Schuster, «The formation and failure of natural dams », Geol. Soc. Am. Bull., vol. 100, no 7, p. 1054-1068, 1988.

22. [G. B. Crosta, P. D. Negro, et P. Frattini, « Soil slips and debris flows on terraced slopes », Nat. Hazards Earth Syst. Sci., vol. 3, no 1/2, p. 31-42, 2003.

23. D. J. Varnes, «Landslide Types and Processes », p. 28. 